http://spilplus.journals.ac.za/

\title{
NORMERING IN DIE AFRIKAANSE RADIO- EN TELEVISIEDIENS
}

\author{
T.J.R. Botha
}

1. Inleiding

1.1 Prestige en trefwydte

Van al die kommunikasiemedia het die radio en televisie seker die meeste invloed en hoogste aansien. Waar die koerant en tydskrif beperk is tot die geskrewe woord en statiese foto, beskik die radio oor klank en stem; die televisie het tot sy beskikking: klank, stem, die dinamiese beeld en die geskrewe woord. Die kommunikasie is intiemer, persoonliker, direkter as die van die pers. Ook reik dit verder: dit betrek die gesin as gesin; selfs die kleuter wat nog nie kan lees nie, is binne bereik van die radio en televisie.

1.2

Taal beklee ' $n$ sentrale plek in radio- en televisie-uitsendings. Die aansien en beeld van die SAUK hang ten nouste sear met die gehalte van die taal wat gebruik word. Dit besef die SAUR. Weens die prestige van die radio en televisie as media en die ruim benutting van die uitsendings moet die taal wat in programme gebruik word, onvermydelik invloed ultoefen op die taal van die luisteraars. Cok hiervan is die SAUk bewus. Die SAUK aanvaar dat hy ' $n$ taalverpligting teenoor die gesin, die onderwys, die samelewing het. Dit blyk onder meer uit die aanstelling van taaladviseurs en taaladvieskomitees vir die onderskeie dienste, die aandag wat deurentyd aan taalversorging bestee word en die verskeidenheid tegnieke en metodes wat afdelingshoofde aanwend om hulle personeel op hoogte van taalsake te hou. 
http://spilplus.journals.ac.za/

Die programme warna die publiek kyk en luister, is die finale, afgeronde produk. Min luisteraar-kykers hẹt 'n indruk van die omvang en aard van die taaleise wat die voorbereiding en versorging van programme aan die personeel stel. Op die Afrikanse Diens rus nog die bykomende las van ' $n$ massale hoeveelheid vertalwerk uit ' $n$,verskeidenheid tale. Die programme handel oor enige denkbare tema --- van populêr tot wetenskaplik, van kleuterverhaal tot wêrelddrama, van die plaaslik bekende tot obskure plekke, mense, diere, plante, en so meer. As internasionale medium en ou kultuurtaal het Engels in voorsprong op Afrikaans. Nietemin word dit van die Afrikaanse Diens verwag dat die taalkwalfteit van sy programme gelykwardig aan die van die Engelse Diens moet wees. Enersyds bied dit ' $n$ grootse uitdaging aan Afrikaans; andersyds stel dit geweldige eise aan die personeel van die af rikaanse Diens. Afrikaans is ' $n$ jong kultuurtaal. In verskeie opsigte is dit nog nie so geyk, gestandaardiseer en genormeer soos ouer kulturtale nie. As vertaaltaal skiet sy woordeskat soms te kort. Probleme word byvoorbeeld nog ondervind met watersportterme. Ten opsigte van vorm, spelling en uitspraak van vreemde elename, wat ' $n$ hoë frekwensie in nuuberiggewing het, heers nog groot onsekerheid. Bedink hierby dat die Afrikanse Radioen Televisiepersoneel nie noodwendig opleiding in Taalkunde ontrang het nie. Taalgebruiksvermoë is slegs een van die vereistes by aanstelling. In hierdie omstandigheid is dit te begryp dat die personeel die hulp nodig het van ' $n$ taaladviseur en in taaladvieskomitee wat kan help toesien dat die taalgebruik aan erkende normatiewe eise voldoen en norme kan opstel waar dit nog ontbreek.

Normering van taalgebruik in die Afrikaanse Radio-en Televisiediens is in eerste instansie -- maar nie uitsluitlik nie --- toegespits op die toepassing van algemeen erkende norme. Die opstel van norme word slegs onderneem vir daardie aspekte warvoor daar nog nie norme bestaan nie en waarvoor die Afrikaanse Diens wel normering nodig het. Dle SAUk self tree nooit as mededingende opsteller van norme op nie. Die gesag van gesaghebbende normerende liggame word erken en die norme wat deur dergelike liggame opgestel is, word eerbiedig. tensy dié norme kennelik.strydig met die huidige reëls van Alrikaans is of om die een of ander nie-taalkundige oorweging noodwendig gewysig moet word. 
http://spilplus.journals.ac.za/

Die enigste amptelike liggaam wat belas is met die normering van Afrikaans binne SAUK-verband, is die KTA. Sedert sy totstandkoming sowat veertig jaar gelede het die KTA heelwat gedaanteverandering ondergaan.' In 1982 het dit uit slegs ses lede bestaan: twee personeellede, namlik die Hoof: Afrikaanse Diens en die Taaladviseur: Afrikaanse Dienste, bygestaan deur vier buitelede, almal professore in departemente Afrikaans en Nederlands, wat deur die Dizekteur-generaal van die sauk vir in termyn van drie jaar aangestel word. Ter wille van groter doeltreffendheid, meer eenvormigheid en hegter samewerking op taalgebied tussen al die dienste warin Afrikaans gebruik word, is die ledetal in Desember 1982 na veertien uitgebrei met die roevoeging van die volgende senior personeel: die Opsiener: Oorklankvertaling, die Opleidingsredakteur: Nuus, die Hoofde: Radionuug, Televisiediens, Springbokradio, TU $I$, en streekdienste en Radio 5 , met die Direkteur: Afrikaanse en Engelse Radiodienste as voorsitter. Die Taaladviseur tree op as sekretaris. ${ }^{2}$

Die RTA vergader tweemaandeliks in Johannesburg. Drie weke voor die vergadering besorg elke buitelid aan die Taaladviseur 'n taalrapport waarin wargenome talfoute gerubriseerd aangestip word, met vermelding van die program warin dit voorgekom het en, war nodig, me t die "korrekte" vorme bygevoeg. Ook gunstige kommentaar oor programme met 'n hoë peil van taalversorging en treffende styl word in die taalrapporte gelewer. Benewens die taalrapporte plaas die Taaladviseur van die taalprobleme op die agenda wat hy in die loop van die twee maande tussen vergaderings teëkom en nie raad mee weet nie, byvoorbeeld die Afrikaans vir golden hand-shake en hitman, of die toelaatbaatheid van plant in ' $n$ konstruksie soos 'n boo in 'n gebou plant; oox die beslissings wat hy noodgedwnge inderhas moet gee en warvan hy die geldigheid enigsins betwyfel. Dit staan die personeel vry om probleme na dle KTA te verwys, gewoonlik via die Taaladviseur. 
http://spilplus.journals.ac.za/

Die Taaladviseur (Afrikaans) is die enigste personeellid in die sauk wat amptelik verantwoordelik is vir alle aspekte van talnormering by al die Afrikaanse dienspunte. ${ }^{3}$ As 1 id en sekretaris van die kTA beklee hy ' $n$ sentrale posisie in die liggaam. In sy hoedanigheid as Taaladviseur beklee hy ' $n$ sentrale. maar ook 'n sensitiewe taalgesagsposisie binne die konstellasie Afrikaanse radio- en televisiedienspunte.

Uit hoofde van sy amp en weens die besondere aard van die werksaamhede en werkseise van die SAUR word dit van die Taaladviseur verwag om nie net uitsluitsel te kan gee oor ' $n$ wye verskeidenheid taal-en vertaalkwessies nie, maar heel dikwels ook met bekwame spoed, selfs onmiddellik. In sy daaglikse werk kan hy uiteraard nie noodwendig staatmak op die dickte hulp van die KTA nie. Gewoonlik is hy man-alleen aangewese op sy parate taal- en talekennis, en war dit ontoereikend is, moet hy hom verlaat op standaardbronne of vakoutoriteite, vir soverre dié bestaan en beskikbaar is. Ter lllustrasie: Die USSR kies in nuwe leier -- Andropof. Oor 'n kwartier of wat moet sy naam op die televisieskerm verskyn en moet die nuusleser dit "korrek" kan uitspreek -- "in Afrikaans". Moet Andropof met slot-v of -f op die skerm verskyn? Waar lê die noofklen in die uitspraak --- op die eerste, tweede of derde sillabe? lemand moet weet, minstens dle taaladyiseur, ongeag of daar oordragnorme vir die transliterasle en vitspraak van Aussiese woorde in afrikaans bestaan of nie. En hierdie voorbeeld is nou nie fuis een van die gekompliseerdes nie.

Die Kantoor van die Taaladviseur funksioneer as kommunikasiesentrale tussen die KTA en die personeel van die netwerk dienspunte waarin Afrikaans gebruik word, in die Republiek en in die buietland. Hiervandaan word die besluite van die KTA, en ook die wat die Taaladviseur onathanklik van die KTA neem, na die verskillende afdelings of dienste versprei. via die kantoor van die Taaladviseur bereik talnavrae, versoeke om hersiening van besluite, kommentaar op genormeerde items, en so meer die kTA. 
Geen moeite word ontsien met die verspreiding van taalbesluite onder die personeel nie. Die uitgangspunt is: Hoe beter die personeellede ingelig word, hoe beter die eindproduk, dit wil sê die gehalte van hulle taalgebruik: hoe meer genotmeerde gegewens aan hulle verstrek word, hoe minder tyd hoef hulle aan onsekerhede te bestee, met die gevolg: groter produktiwiteit. Verder -.- as personeel van voldoende inligting voorsien word, boonop in gerieflike format, volg dit dat daar van hulle verwag kan word om dit te beheers en toe te pas.

Die hoofde van die verskillende dienspunte ontvang afskrifte van die notules van die KTA-vergaderings, wat na goeddunke en eie behoeftes benut word.

$\mathbf{5 . 2 . 2}$ Kaartjiesteisel

Die Taaladviseur laat die besluite van die KTA op kattjies aanbring wat in twee stelle alfabeties gerangskik word, naamlik oitspraakkartjies en Taalkaartfies, warvan die moederstel by die sAuk in Johannesburg gehuisves word, terwyi duplikaatstelle aan al die streekredakteurs en Programorganiseerders van Afrikaanse nuuskantore besorg word --- altesame meer as twintig verspreidingspunte in die vier provinsies. Die twee stelle kaartjies, wat gereeld aangevul en bygewerk word, is tot die beskikking van alle personeellede en medewerkers (Taalbulletin 1984:3; mededeling van Taaladviseur).

Advieslyste en -memorandums word deur die Taaladviseur aan 'n ruim persentasie van die personeel gerig. Hierdie omsendbriewe word angevul met "dagopdragte" waarin onder meer besondere kTA-besluite rerskyn. aantekeninge 
http://spilplus.journals.ac.za/

oor die taalgebruik van indiwiduele nuusskrywers en taalkommentaar van luisteraars. Hierdie omsendbriewe het die voordeel dat dringende besluite die personeel sonder versuim beieik; ook het dit ' $n$ groter en gevoeliger impak as die taal- en uitspraakkaatjies op 'n personeellid as gevolg van die veel direkter, meer persoonlike gerigtheid daarvan (Taabulletin $1984: 41$

Die personeel van die Nuusafdeling hou gereeld redaksievergaderings. Uit die aard van die saak is taalsake slegs een van die vele aspekte wat bespreek word. Die besluite, uitsprake en advies wat uit hierdie vergaderings voortvloei, word in die vorm van aantekeninge, huishoudelik die Muuskliniek genoem, onder die personeel (redakteurs, joernaliste, nuuslesers...) van die Nuusafdeling versprei (Taalbulletin 1984:8).

Die taalaatekeninge in die Nusskliniek hou onder andere verband met die gehalte van die skryfwerk van redaksielede, byvoorbeeld korrekte taalgebruik, gangbare styl, ortografie, ensovoorts, onder meer gemeet dán die norme wat die KTA voorskryf. Weens die aard van sy werk is die Nuusafdeling blykbaar verplig on bepaalde aspekte van taalgebruik onafhanklik van die KTA en die Taaladviseur te normeer, meer bepaald aspekte wat samhang met diplomatieke betrekkinge, byvoorbeeld die gebruik van die Republiek van sjina in plaas van Taiwan (waaroor die betrokke staat sensitief voell: met protokol, byvoorbeeld die aanspreekvorm Miniater in onderhoude met in minister; met etnisiteit en groepverhoudings, byvoorbeeld die vermyding, sover moontlik, van wit, bruin, swart, en so meer in verwysings na indiwidue en groepe. soos volg uit: 
"In die nuusbedryt het ons te doeñ met ' $n$ hoogs bederfbare produk (wat vinnig gehanteer moet word)." (Taalbulletin 1984:2)

Op ' $n$ enkele werkdag ontvang die Nuusredaksie sowat tweemiljoen woorde kopie cor 'n verbasende verskeidenheid onderwerpe, hootsaaklik in Engels. Binnelands is daar 'n paar honderd beriggewers wat 'n 5wart taal gebruik. In die Nusafdeling. moet daar dus op besonder groot skaal vertaal word. Hierby moet toegevoeg word die massale hoeveelheid vertaalwerk (dramas, dokumentêre, ensovoorts) wat die Televisiediens moet behartig, veral uit Duits, Frans, en selfs Engels. Met verwysing na die Nuspersoneel merk mnr. Carel van der Merwe op:

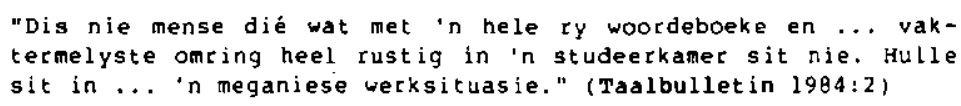

In so ' $n$ veeleisende werksomstandigheid is die genormeerde materiaal wat onsistematies versprei lê in omsendbriewe en aantekeninge, en in stelle kaartjies buite jou onmiddellike bereik, soms betreklik ondoelmatig. Wat die Radio- en Televisiepersoneel eintlik nodig het, is ' $n$ kitsgids in gerieflik hanteerbare format warin die material volgens ' $n$ praktiese sisteem georden en in ' $n$ nie alte tegniese taal gestel is. Met die samestelling van die Taalbulletin het die Nusafdeling in 'n mate in hierdie behoefte voorsien.

\subsubsection{Seleksie van materiaal}

Die Taalbulletin is nie ' $n$ kompilasie van al die gegewens op die Taal- en oitspraakaartjies en in die omsendbriewe en ander stukke nie. Dit bevat slegs 'n seleksie daaruit, ' $n$ seleksie wat gebaseer is op huidige perscneelbehoeftes, byvoorbeeld norme wat nog herhaaldelik oortree word, soos Anglisistiese klem ('n 'kowplekse verskynsel, 'kontrak): morfologiese onreëlmatighede (die wees ingevikkeldste in plaas van die mees ingevikkelde of die ingewikkeldste); foutiewe skryfwyses, veral van samestellinge (TyNuus in plaas van rv-nus, televisie lisensie in plas van televisielisensie): die vorm van eiename (Brussels in plaas van Brussel, poland in plas var pole). Ter wille van die vertalers word 'n ruim aantal 
http://spilplus.journals.ac.za/

T.J.R. Botha 245

Engelse woorde en uitdrukkinge ingesluit, byvoorbeeld jaming: belemaering ('n radioterm); jet lag: vlugtamheid; live broadcast: regstreekse uitsending; time-sharing: tyddeel, tyddeling ('n eiendomsterm). Verskeie taboeverklaarde items is opgeneem: komper vis die aanvaarde rekenaar en rekenoutomat; kontak as werkwoord, ensovoorts.

\subsubsection{Alfabetiese ordening}

Die material is alfabeties gerangskik, ongeag of die trefwoorde Afrikaans of Engels, zulu, ensovoorts is. Selfs vreemde eiename (Hongkong, Matanziwa) en temas (hom-sinne, hoofletters, Portugese name, Weermagrange) verskyn alfabeties tussen die leksikale items. Die Eunksionele gebruik van kruisverwysing vergemaklik naslaanwerk, byvoorbeeld naas voorstellingsparade is daar ook ' $n$ inskrywing passing out parade.

\subsubsection{Styl en trant op samewerking gerig}

Die Taalbulletin is uitsluitlik vir huishoudelike gebruik bestem; daarom is dit nie volgens streng leksikografiese beginsels gestruktureer nie. Die bewoording, terminologie en styl klink in bale gevalle soos dié in korrespondensie tussen kollegas, die aanslag hoflik en informeel, soms selfs ietwat te intien. Dié benadering het die voordeel dat dit eerder samewerking en belangstelling in personeelgeledere wek as wat dit afskrik en vervreem. Van die aantasting of onderdrukking van Indiwidualiteit is nêrens sprake nie. Inteendeel --- by de radio en televisie is indiwidualiteit juis in aanvragi: dit werk verskeidenheid van aanbieding in die hand. Dit staan ' $n$ personeellid volkome vry om sy indiwidualiteit op sy werk af te stepel, mits hy dit doen binne die ruimte wat die norme hom veroorloof. Per slot van rekening wil die Taalbulletin 'n hulpmiddel wees. 


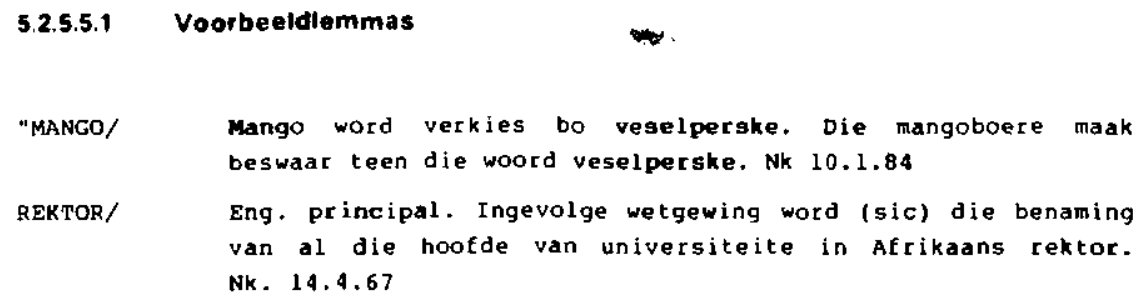

VERLOF / Ons sê op verlof of met verlof. Tk 11.66 "

\subsubsection{Erwerking on rekenarlsering}

Die raalbulletin is op so 'n wyse gebind dat aanvullende blaaie sonder moeite ingevoeg en gewysigdes vervang kan word. Ter wille hiervan word die bundel in getikte vorm behou. Bowendien is die SAUk van voorneme om al die matertaal binne afsienbare tyd te rekenariseer.

"Ulteraard moet die uitsaaier wat beroepsman wil wees en wil bly, bly slyp en herslyp aan sy taalvaardigheid", aldus mnr. J.E. van $z_{Y}$, Adjunk-Direkteur-generaal: Nuus (Taalbulletin: voorwoord). Blykbaar sal die Taalbulle tin na rekenarisering steeds in gebruik bly as opleidingsinstrument vir veral onervare personeellede van die sauk en buitemedewerkers (byvoorbeeld. vryskutvertalers), en mettertyd vir studente in die tersiêre onderwys.

Tydens onderhoude met applikante word hulle taalbeheersing getoets aan die materiaal in die ralbulletin. In sommige afdelings van die Afrikanse Diens lê personeel taaltoetse af wat gebaseer is op die Bulletin en dien die peil van hulle taalbeheersing as ' $n$ matstaf by gradering en bevordering (Volgens in senior amptenaar tydens die KTA-vergadering van 3.10.84). 
http://spilplus.journals.ac.za/

Die gesag van die KTA-besluite' en die sukses met die toepassing van die besluite hang in ' $n$ groot mate af van die taalhouding, normbewustheid en inisiatief van toesighoudende amptenare en afdelingshoofde (N 1984. 10).5 Die warde wat die Raad van die SAUK, die topbestuur en die personeel oor die algemeen heg aan die openbare beeld en aansien van die SAUR --- en die beeld en aansien hang ten nouste saam met sy taalbeeld --- behoort op sigself 'n stimulecende uitwerking te hê op die mate warin die taalnorme inslag $v i n d$ en toegepas word in die personeelgeledece van die Uitsaaikorporasie, tensy die norme strydig is met die reëls van Afrikaans.

Die doelwit van die normeerders is "korrekte" taalgebruik, "korrek" in die sin dat die taalgebruik in ' $n$ bepalde program, byvoorbeeld die Nuus, Oordenking, sportkommentaar, poësievoordrag, onderhoude met dle publiek en kleuterprograme, moet beantwoord aan die aanvarde taalgebruiksnorme en vereistes vir in program in dié besondere genre, kader of kategorie, dit wil sê met inagneming van die gewenste kode(s), sodat die taalgebruik met betrekking tot styl, register, situasie, die rol van die spreker(s) of karakter\{s\} en so meer naturik verloop, nie kunsmatig of geforseerd aandoen nie (vergelyk (Odendal 1984:271 e.v.)). Die radio en televisie is taalgevoelige media. Die boodskap, berig, beeld, inhoud moet die luisteraar-kyker "langs die weg van die minste weerstand" bereik. Per program moet die taal warin 'n gegewe na die publiek gesein word, so gepas en korrek moontlik wees, dit wil sê dit behoort sover moontlik vry te wees van kommunikasiesteurnisse, -hinderlikhede, -versperrings, -skokke, taalfoute...., sodat die interaksie tussen enkodeerder (uitsender) en dekodeerder (luisteraar, kyker) glad en sonder spanning kan verloop. Per program moet die taal wat gebruik word as't ware deursigtig wees, gepas en in harmonie met die situasie: nie te formeel, te informeel, platvloers, hoogdrawend, te deftig, te gemeensaam ... wees nie. 'n Enkele ontsporing of taalflater kan die luisteraar-kyker ontstel, ontstem, dit wil sê die kommunikasie versteur, byvoorbeeld: 
http://spilplus.journals.ac.za/

(a) In ' $n$ televisie-onderhoud spreek die omroeper 'n Administrateursvrou in ' $n$ formele situasie aan met $y$ in plaas van u. Die tipe taalongevoeligheid irriteer die kyker. Dit is ' $n$ vorm van taaigedrag wat afwyk van die erkende norme (vergelyk lOdendal 1984:275 e.v.: 1976:105 e.v.), (van Wyk $1978: 103,117 \%$ ).

(b) In ' $n$ aflewering van die televisiereeks skoppensboer spreek een van ons ervare toneelspelers sinistece uit as [sanaste:ro] in plas van sinistexe (so'nastzra), blykbaar na (valse) analogie van woorde soos sekon'dêr, inflasio'nêr, ensovoorts. In 'n ander program is kentering vertrek tot [ken'te:roj]! Dergelike aksentfoute lyk na iets gerings, mar. eintlik is hulle gruwelik steucend.

(c) 'n Origens puik uitsending van ' $n$ boksgeveg on die wêreldkroon word ontsier met ' $n$ enkele Anglisistiese konstruksie: "In hierdie stadium is Crous beslis die beter van die twee boksers" in plaas van die beste.

6.2

\section{Korrekte spelling en skrytwyse}

6.2 .1

Inleiding

Voor die instelling van die Televisiediens in 1976 het die skriftelike gebruik van Afrikaans die publiek nie geraak nie. Sedect 1976 verskyn Afrikaans op die skerm. Die luisteraar is nou ook kyker en leser. Die geskrewe woord kry in rol vóór, ná en dikwels ook in 'n program, en gereeld in advertensies.

Die RTA strewe doelbewus na die noukeurige toepassing van die beginsels en reëls wat vir die spelling en skryfwyse van Afrikaans opgestel is deur die Taalkommissie van die Suid-Afrikaanse Akademie en in die Afrikanse voordelys en gpelreëls verskyn, met aanvullings in die Nuusbrief van die Akademie. 
http://spilplus.journals.ac.za/

Die akademiese kwallfikasies, taalvermoë en graad van geskooldheid in die beheersing van Afrikaans wissel van personeellid tot personeellid. Van sommige is Afrikaans bloot die sekondêre taal, veral in die handelsdienste. Een van die belangrike oogmerke van die kTA is om by wyse van deurlopende korrektiewe hulp en advies die peil van die taalgebruik van die personeel op ' $n$ gesonde vlak te probeer hou, om twyfel vit die weg te ruim, sodat elke personeellid met 'n gevoel van taalsekuriteit sy werk kan doen.

Wat die KTA hom ten doel stel is 'n gehalte taalgebrulk wat in ooreenstemming is met die aansien van die SAUR, wat tred hou met die ontwikkeling van Afrikaans en wardeur die peil van Afrikaans in die gemeenskap bevorder kan word.

\section{Vorm waarop normering gerig is}

Die meeste programme in die Afrikanse Diens is bestem vit 'n volwasse luisteraars- en kykerspubliek. Oie temas, aard en (intellektuele) vlak van die meerderheid programme is sodanig dat hulle aangebled moet word in standaard-Afrikaans, selfs programme wat op volwassenes én kinders ingestel is, byvoorbeeld sportuitsendings en baie dokumentêre. Programme vir laerskoolkinders is wel in eenvoudiger taal geklee, mar tog nog in die standaardvorm.

Substandaardtaal is in sommige aanbiedinge onontbeerlik, en daarom geoorLook, byvoorbeeld in dramas warin een of meer karakters figureer wat ' $n$ streekvariant of 'n sosiolek gebruik. 'n voorbeeld hiervan is siener in die suburbs (1972) van P.G. du Plessis warin die dialoog die karakters so- 
sial-ekonomies merk. In sommige van hulle ("luister"-lliedjies gebruik liedjieskrywer-sangers soos Anton Goosen en. David Kramer substandaardwoorde, -uitdrukkings en -uitspraak heel effektief. Word die liedjies ongestel in standaard-Afrikaans, is hulle styl daarmee heen -.- én hulle trefkrag. Op sommige gebiede van die skeppende en uityoerende kuns het die substandaardvorme van Afrikaans 'n eiesoortige funksie, voorsien dit in ' $n$ behoefte en het dit dus bestaansreg naas die sogenaamde "beskaafde" taalvorm: In somige werke is dit struktureel geïtegreer en onvervangbaar; dit bevredig die luisteraar-kyker esteties; boonop het dit komersiële waarde, onder andere vir die kunstenaar. Dit is dus te begrype warom ook produsente en verspreiders van produkte soms die trefkrag van die taalvorm in hulle radio- en televisie-advertensies benut (Odendal 1984:263-269).

In Voorskrifte en versoeke aan die vertalers van dramas vir taaloorklanking (1983:33) van J. Moodie word onder die opskrjf "Onaanvaarbare woorde" onder andere die volgende verstrek: beneuk, blercie, bllksem, donder, jirre, jou teef, wers, opneuk, ook baai-baai en koebaai: onder "Aanıaabaa: 5 !egs in uitsonderlike gevalle" onder andere die volgende, met verdere kwalifisering na elk: jou vuilgoed ("net in bepaalde gevalle"); duiwelskind, verduivels ("met oorleg"); jis, jip, chips, chow ("slegs waar in karakter"--- vermy"); okay, oraalt ("in uitsonderlike gevalle waar in karakter -.. vermy"); jop, joppie, tjeers ("slegs waar in karakter"), met die slotopmerking: "In alle gevalle moet goeie smaak en oordeel die deurslag gee". Die estetiese aspek en funksionaliteit word hier dus as kriteria by normering aangewend.

In oorspronklike Afrikaanse dramas wat in 1984 gebeeldsend is, kom gevalle soos die volgende voor: As hy uituind, is die hel 108 , Hou jou bek, en Eng. try (probeer) in Die Hoogste Bod; Ek werk ey vrek in Die Dood van bermien Adler; studentetaal in Trans-karoo: 'n bok vir fliek, universiteite is trick-fabrieke, dis peanuts en guts hê. Nóg die publiek nóg die KTA het beswar hierteen geopper, blykbanr omdat die sleng- en swetsvorine redelik geintegreer was in die onderskeie stukke. 
http://spilplus.journals.ac.za/

Afgesien van bepaalde taboewoocde en -uitdrukkinge wat in geen program mag voorkom nie, is substandaardtaal geoorloof in sekere programme, bo en behalwe dramas en liedjies, warna vroeër verwys is, mits dit nie bepaalde perke oorskry nie. Hierdie "perke" word nie gedefinieer nie. Daar word staatgemak op die insig, oordeol en ervaring van die personeel, professionele mense wat intuitief, op grond van opvoedkundige, etiese en estetfese oorweginge, en aan die hand van gebruiksgevalle wat tot dusver deur die kTA goed- of afgekeur is, behoort te weet wat toelaatbaar is en wat nie.

Alle aspekte van taalgebruik kom in aanmerking vir normering, maar nie in gelyke mate nie. Uitspraak (veral woordklem), skrytwyse (samestellinge, koppeltekengebruik, hoofletters, deeltexens, vreemde eiename) en Anglisismes vereis byvoorbeeld baie meer normering as spelling, woordvorm en sinsbou. Hierdie oneweredigheid word nie deur die willekeur van die KTA meegebring nie. Die KTA sonder nie spesifieke aspekte vif normering uit nie. Die oorgrote meerderheid van die material wat op die agendas vir die KTAvergaderings voorkom, bestaan vit taalfoute, normoortredings, wat onwillekeurig uit programme opgeteken word. Dardie aspekte van Afrikaans wat die meeste ontsporings oplewer, word dus die meeste aan normering onderwerp, en omgekeerd. ' $n$ Mens sou dit ook so kon beskou: Hoe groter die normatiewe onvastigheid of onsekerheid wat Afrikaans met betrekking tot in bepaalde aspek vertoon, hoe groter die behoefte aan normering. In Moontlikheid warmee ook rekening gehou moet word, is dat wispelturigheid op die gebied van normtoepassing verband kan hou met normweerstand, verset, -verwerping, selfs norm-ignorering, in verskynsel wat die normeerder nie met verantwoordelikheid kan negeer nie. Van die verskeidenheid aspekte word vervolgens slegs enkeles ter illustrasie van nader beskou. 
http://spilplus.journals.ac.za/

Hoewel die Uitspraakwoordeboek van Afrikaans van Leroux en Pienaar plekplek verouderd geraak het en ook na inhoud nie toereikend is vir die behoeftes van die SAUK $n i e$, is dit nog steeds" n bcon van gesag, aiskien van te veel gesag, soos uit sommige van die volgende paragrawe sal blyk.

Ronding van (a:) tot (s:J, byvoorbeeld (mo:ndaxps:nt p'a s drsima po:nt) (Maandagaand is drama-aand), het die afgelope jaar of vyf opgeduik, veral onder kontinuiteitsaankondigers. In die rubciek "TV" van Rapport (1984-3-4) word te velde getrek teen "hierdie anslag op die Afrikanse vokal" na aanleiding van die uitspraak "jô, Pô" vír "ja, Pa". Blykbaar is hierdie tendens, wat glo tamlik verbreid is onder die jeug van gegoede gemeenskappe in Pretoria en Johannesburg, minstens voorlopig in SAuk-geledere hokgeslaan.

Ontronding van vokale en diftonge in betoonde sillabes kom wel voor, maar eintlik heel selde, byvoorbeeld dink (in plas van dunk), hille (in plas van hulle\}, kleter (in plaas van kleuter), lyster (in plas van luister), Pt en Tys (in plaas van Uit en Tuis), veiligheid (in plaas van vuiligheid).

\subsubsection{Elisie van $[r]$}

Die weglating van $[r]$, byvoorbeeld in die uitspraak van daarmee, warom, kom gereeld voor; tog word dit selde in KTA-vergaderings of in taalrapporte aanhangig gemaak. 'n Uitsondering is [bofo:bolt] (byroorbeeld), wat "liewer" as [bafo:rbe:lt] uitgespreek moet word (N 1984-10). Sou die gelatenheid oor die [r]-lose uitspraak daarop dui dat dit as $n$ vorm van uitsprakverandering beskou word? Myns insiens is dié uitspraak, wat 'n kenmerk is van die Afrikaans van Engelstaliges, substandaard. 
http://spilplus.journals.ac.za/

\begin{abstract}
8.2 .5
Anglisistiese konsonante

Die vervanging van (j\} met $\{$ dj $\}$ in woorde soos judo, junior, junta en Jupiter word as Anglisisties bestempel. Die /d l is in orde in kollege (onderwys-), mar nie in kieskollege nie, war ' $n$ \{ $\boldsymbol{J}\}$ vereis word: [kisko le:30) (N. 1982-12), 'n beslissing warby daar stellig nje voldoende reke-

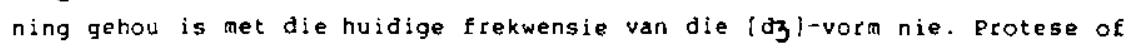
vooraanvoeging van $|j|$ by Jnisa en Dnita word afgekeur; eweneens invoeging van $[j]$ na $[n\}$ in die tweede sillabe van wonument en na $[m]$ in die eerste sillabe van wuseus.
\end{abstract}

8.2.6 Letteruitspraak

Letteruitspraak. word sonder meer afgekeur, selfs war daar van 'n teks af gewerk word. ọie uitspraak van pasiënt met [s] word verwerp ten gunste van dié met $(f)$, in ooreensteming met Le Roux en pienaar (1976:167); ook by spesiasl, waarby le Roux en Pienaar (1976:208) wisselvorme met \{s\} en [f] verstrek. Hiecteenoor word vereis dat oseaan met \{s\} uitgespreek word. Die tweede konsonant in posisie kan met (s) of [z] uitgespreek word, dog by voorkeur met [s]. Dit is te begrype dat letteruitspraak soms voorkom by vreemde eiename warmee ' $n$ omroeper nie vertroud is nie, byvoorbeeld Arkansas \{'a:kensJ(:)\} as [a:'ka nsas], ballasteros met ' $n$ [1] in plaas van in $(j]$ in die tweede sillabe, Connecticut [kanetikət] met ' $n[k \mid$ aan die einde van die tweede sillabe, Junker (vliegtuig) as [jøykər] in plaas van \{jugkar], Lelcester $\{$ lesto] met drje in plaas van twee sillabes.

8.2.7 Aksent

8.2.1.1 Inlelding

woordaksent is een van die aspekte wat die meeste prableme oplewer. Die woorde warby foutiewe aksentplasing voorkom, varieer van doodgewone, eenvoudige gevalle tot tipes wastby aksentverskuiwing ingetree het of an die intree is. 
http://spilplus.journals.ac.za/

Enkele voorbeelde is eer'gister in plas van 'eergister, land'warts in plaas van 'landwaarts, 'orlewendes in plaas van oor'lewendes, 'oornag in plaas van oor'nag (bw.). 'ongewing in plaas van ow'gewing, 'omliggende (gebied) in plaas van on'liggende, oor'konde in plaas van 'oorkonde. ver'ontrus in plaas van veront'rus. Die uitspraak 'aangrensende in plaas van aan'grensende hou moontlik verband met die twee aksentpatrone wat in (Le Roux en Pienaar 1976:1) aangegee word, dog die KTA oordeel dat aan'grensende teenswoordig die gebruiklike vorm is.

\subsubsection{Woorde op -kus}

\subsection{Tradislonele aksentpatroon}

By die klas woorde wat eindig op -kus, byvoorbeeld 'medikus, 'muslkus, he'raldikus, po'litikus, met meervoude 'medici, 'oedikusse, po'litici, po'litikusse, ...., val die hoofklem tradisioneel op die eerste of daaropvolgende sillabe, maar nie op die laaste sillabe (-kus, -cil of die voorlaaste (tegni'kusse) nie. In (Le Roux en Pienaar 1976) is dit deurgaans die reël. Tot dusver erken dle KTA eweneens slegs hierdie patroon.

\subsection{Moontlike klemverskuiwing}

Ten spyte van die KTA-voorskrif word daaf in die talrapporte met eentonige reëlmaat voorbeelde voorgelê van gevalle warin die hoofaksent na die slotsillabe verskuif is, byvoorbeeld heraldi'kus, akadewici, of na die voorlaaste sillabe, byvoorbeeld ausi'kusse. En dit ten spyte daarvan dat elke "afwyking" telkens gekorrigeerd onder die personeel gesirkuleer word. Word hierby in ag geneem hoe algemeen hierdie "afwyende" aksentpatroon in die omgangstaal voorkom, ook van "beskaafdsprekendes", is dit geregverdig om te vra of daar by nierdie kategorie woorde nie klemverskuiwing ingetree het nie, ' $n$ verskuiwing van so ' $n$ graad dat die uitspraaknorme dit behoort te akkommodeer, minstens as wisselpatroon naas die tradisionele. Daardeur kan die spanning tussen norm en ' $n$, taalverandering ontlont word. 
http://spilplus.journals.ac.za/

Die Afrikaanse, Nederlandse en Engelse woordeskat bevat ' $n$ aansienlike groep gemeenskaplike woorde van; Griekse, Latynse en veral Franse herkoms. (Vergelyk (Combrink 1984:84 e.v.); (Raidt s.j.: 17 e.v.. 34 e.v.. 75 e.v., 169 e.v.1). Met betrekking tot betekenis kom hierdie woorde meestal ooreen in die drie tale, maar ten opsigte van aksentplasing is daar ' $n$ aanmerklike verskil. Vergelyk byvoorbeeld Eng. 'aspect -- Afr. as'pek; 'dialogue -dia'loog, 'formal -- tor'meel, 'contact -- kon'tak, 'contract -- kon'trak; 'minister -- minister; 'primary -- pri'mêr; iproject -- pro'jek; 'telephone -- tele'foon; 'telescope -.. tele'skoop. In standaard-Afrikaans word hierdie woorde en talle ander uit hierdie klas dikwels met die Engelse aksentpatroon gebruik. Dit is duidelik dat die tradisionele patroon in hedendagse Afrikaans erg versteur is (kirsten 1981:113 e.v.). 'n Verandering het ingetree wat nie ligtelik weggenormeer sal kan word nie. Volgens die bevinding van kirsten (t.a.p.) is die verhouding tussen die gebruik van die Engelse en die voorskriftelike Afrikaanse aksentplasing by (byvoorbeeld) die volgende woorde persentasiegewys respektiewelik soos volg: absoluut $75: 44$; definitief 67:39; dialoog 44:56; hospitaal 42:58; intellek 51:49; konflik 68:32; kontrak 42:58; Dinister 21:79. Die gemiddeld vir die korpus van 149 woorde wat in die ondersoek gebruik is: die Engelse patroon 52,48 , Afrikaans 47,6 (a.w. p. 114), dit wil sê die benutting van die twee sisteme is sowat gelyk. Ten spyte hiervan is daar olegs B van die 149 woorde waarby al die Afrikanse woordeboeke wat in die kirstenondersoek gebruik is, wisselaksent toelaat, en die oitspraakwoordeboek van afrikaans, pp. 119 e.v. by ongeveer 12 . So in mate van teenstrydigheid tussen norm en taalpraktyk verwar die taalgebruiker, en op die lang duur moet dit die geloofwardigheid aantas van liggame wat moet toesien dat die norme toegepas word.

$\mathbf{8 . 3}$ Invloed van Engels

8.3.1 Inleiding

In die SAUK word Afrikaans nie net aan die invloed van suid-Af Engels blootgestel nie. Vanweë die aard van die werksaamede van die SAUR word Afrikaans bestral deur Engels vanuit al die Engelstalige lande, al die ander lande wat Engels vir internasionale kommunikasie gebruik en nusagentskappe van oral in die buiteland." 
http://spilplus.journals.ac.za/

\subsubsection{KTA as normeerder}

Normering met betrekking tot die invloed van Engels op Afrikaans word gekenmerk deur onvastigheid. Gevolglik is die KTA verplig om hier as medenormeerder op te $t$ ree, nie slegs as toepasser van norme nie.

8.3.2.2

KTA-beleid

Die RTA-benadering van die invloed van Engels kan beskryf word as niepuristies, nie-polities, matig, positief, en veral taalkundig. Die invloed van Engels word as 'n onafwendbare faktor en feit aanvaar --- histories en eietyds. Enige vorm van Engels wardeur Afrikaans verryk is of word, word as ' $n$ wins beskou. Engels word selfs doelbewus benut om leemtes in Afrikaans aan te vul. Andersyds, war dit blyk dat die wesensaard van Afrikans deur Engels aangetas word of dat ' $n$ konstruksie uit Engels ' $n$ Afrikaanse vorm bedreig, word die invloed as onwenslik bestempel en tot Anglisisme vecklaar, tensy dit na die mening van die KTA reeds stewig ingeburger geraak het en dus tot Afrikaans behoort.

\subsubsection{Voorbeelde van erkenning van invloed uit Engels}

Vir afsien (iemand op die lughawe ---) is al baie plaasvervangers op die proef gestel, byvoorbeeld wegsien, groet, totsiens sê, maar blykbaar tevergeefs. Die krieketterm asse (Engeland het die --- behou) en die rugbyterm pak (voorspelers) word aanvar. Die s.nw. flirt word erken; ook flixt as wisselvorm van flirteer. Volle status word verleen aan opblaas as sinoniem vir in die lug skiet, vernietig, byvoorbeeld'n brug opblaas; ook aan skuldig pleit (skuld erken), ieaand sien (spreek), 'n boorgat sink ('n (boorIgat boor). opot en spotvraag (raaiviag). 
http://spilplus.journals.ac.za/

Die leenvertaling dit reën katte en honde voorsien in ' $n$ leemte en word doelbewus aanbevel vir gebruik, omdat die Afrikanse sinonieme uitdrukking gestigmatiseer geraak het as gevolg van pejoratiewe konnotasies wat daaraan geheg kan word. Op grond van sy besondere direktheid van segging word bottelnek as sinoniem nas verkeersopeenhoping, -knoop, -tregter, -knelpunt in gebrulk geneem. Aan Engelse plant, byvoorbeeld "'n bom, dagga, diamante êrens plant", het AErikaans tot onlangs geen behoefte gehad nie. Afrikaans het goed oor die weg gekom met versteek, stel, plaas, en so meer totdat die televisieskerm die ontlening van plant as't ware onafwendbaar gemak het, altans vir bepalde tonele. By die vertaling en oorklanking van televisieprogramme moet rekening gehou word met die sinchronisasie tussen 'n woord wat ' $n$ akteur sê en die stand van sy sigbare spraakorgane. sê 'n akteur op die skerm stel of versteek in plass van die oorspronklike plant, byvoorbeeld in ' $n$ Amerikaanse rampokkerstuk, lyk dit koddig want die uitspraak van die Afrikanse woord vereis nie lipsluiting nie. Waarom dan nie plas in plas van plant gebruik nie? Dit is nog steeds moontlik, mits dit aan die verlangde styl en register yoldoen. Die Engelse hitwan het ' $n$ soortgelyke probleem geskep, totdat iemand met hawer vorendag gekom het.

8.3.5

Anglisismes

Die Anglisismes wat in die Afrikaanse programme opduik, verskil nie juis yan dié wat in die omgangstaal van sprekers van standaard-Afrikaans aangetref word nie.

\subsubsection{Taamlik gevestigde gevalte}

Sommige Anglisismes kom al geslagte lank in Afrikaans yoor en het nog steeds ' $n$ hoë gebruiksfrekwensie, ondanks jarelange volgehoue teenkanting, byvoorbeeld ' $n$ leve mak ('n bestaan maak), stappe need (stappe doen), die perd, atleet lê tweede (die perd is in die tweede plek), by verre (verreweg), die rivier is in vloed (die rivier is vol, kom af), neeste mense glo... (die meeste mense...), 'n rekord breek ('n rekord slaan), welaf mense (ryk, welgestelde mense), jou voete vind (op dreef kom, koers kry), die vet is in die vur (die gort is gar, die poppe dans), beter af vees 
http://spilplus.journals.ac.za/

T.J.R. Botha 258

(beter dataan toe wees), hulle het hulle(-gelf) genlet (hulle het dit geniet).

\subsubsection{1 is die norme nog realisties?}

Is dit, taalkundig beskou, nog geregverdig om ou, geharde "Anglisismes" van hierdie aard in Afrikaans te verbied en as ongewenste invloed te beskou? Die feit dat hulle, ten spyte van al die pogings om hulle te weer, nog steeds floreer, ook in ontwikkelde en opgevoede lae van die gemeenskap --lewer dit nie voldoende bewys dat die gemeenskap hulle nie as ongewens beskou nie? --- dat hulle tóg in ' $n$ behoefte voorsien nie? Moet die krite$r$ ium "graad van ingeburgerdheid" nie swarder weeg by normering nie? Raak ' $n$ norm wat voorskrye dat ' $n$ ontwikkelde werknemer in sy werkkring sy taal minus $\underline{x}$ moet gebruix, nie teenproduktief nie as daardie werknemer voor sy siel weet dat die taalgemeenskap $\underline{x}$ as in integrerende deel van sy standardtal gebruik (en beskou?)? Indien die normering van die $x T A$ ten opsigte van Engelse invloed ontoereikend en te konserwatief is, moet dit stellig daaraan gewyt word dat daar nog te veel rekening gehou word met normering buite SAUK-terrein.

\subsubsection{Jonger Anglisismes}

Van die jonger Anglisismes kan moontlik met sukses geweer word, byvoorbeeld soveel so dat... (in so 'n mate dat...), die aandele is winder duur (... is goedkoper), die partye ontwot dekaar halfpad (... kom mekar tegemoet), rat race (trapmeul), red tape (rompslomp), die seventigs (die sewentigerjare, die jare sewentig), die beslult gaan swar af by die gemeente $1 .$. vind nie juis byval ... nie). Dit lyk nie of Afrikaans behoefte aan die tipe konstruksies het nie: dus lyk dit geregverdíg dat die KTA hulle verbied. Mar wat van "inflasie het gekom on te bly" $1 \ldots$ is 'n permanente verskynsel, ... sal nog lank duur. ... is vir goed hier)? Dit het Afrikaans met gebolde seile binnegevaar en lyk stewig vasgemeer. Die KTA se standpunt is nietemin: Probeer is die beste geweer. Maar jou geweer moet baie optimisme in sy loop hê as jy steakhouse probeer afskiet ten gunste van braaihuis (Taalbulletin $1984: 181$ ). 
In Afrikaans word samestellinge aanmekaar geskryf, in aansluiting by die Nederlandse tradisie (Afrikanse woordelys en spelreëls, 38 e.v.), byvoorbeeld atoombow, wyndistrik, Afrikabeleid, Pordbakkie, Huiggenootartikel. Op die keper beskou is dit 'n eenvoudige, praktiese skryfreël waarvan die toepassing sonder probleme behoort te verloop. Tog word die reël gereeld oortree, nie net by die SAUk nie, maar ook in ander sfere, in die koerant-en advertensiewese stellig die meeste. Blykbaar word die reëlafwyking veroorsaak deur die Engelse skryfwyse warvolgens 'n groot persentasie van die konstruksies wat in Afrikaans as samestellinge beskou sou word, los geskryf word, byvoorbeeld vine district, Africa policy. Ford bakkie.

\subsubsection{Tipes waarby normoorteding voorkom}

Die tipes sametsellinge warby die los skryfwyse dikwels aangetref word, is onder meer die volgende:

(a) Soortnaam + soortnaam, byvoorbeeld aarbel sjokolade, widdelslag wotors, mode vaardes, somer voorkoms, verjaarsdag verkoping, Winskoop Verkopings (in Afrikaans aanmekar en sonder hoofletters).

(b) Eienaam + soortnaam, byvoorbeeld Afrika manter, Aigoa baal, coca Cola bottelaar, Daw vloeiroom, Phantom straaljagters, Snackwich roosters, Springbok krieketspeler. By 'n groot persentasie word die tweede komponent met ' $n$ hoofletter geskryf, volgens die gevestigde Engelse model, byvoorbeeld Africana Museun, Boland Bank, Hoofstad Bouvereniging, Mazda Superbakkies, RGN Ondersoek, Sanlam S.A. Beker Byeenkons, Trust Bank, Onited Bouvereniging.

\subsubsection{3} Oorsaak van reelatwrking

\subsubsection{1 'n Verlengstuk van tealbelhvloeding}

In Suid-Afrika het ons ' $n$ diglossiese taalsituasle: Engels word vir meer hoër funksies gebruik as Afrikaans. Vergelyk (Ponelis 1984:30-41); (Steyn 
http://spilplus.journals.ac.za/

1980:15 e.v.); (Van Wyk 1978:115-116). Engels oorheers in die stede, in die handel en nywerheid, in die reklameweste, in die vermaaklikheidswereld, op letterkundige gebied, as wetenskapstal, en so meer. Deur die tweetaligheid van die Afrikaner het Engels sy sekondêre taal geword. In sy werkkring is Engels dikwels selfs sy "eerste taal" (Ponelis 1984:33). Die Afrikaner is dus voortdurend op groot sxal blootgestel aan Engels. Een onvermydelike gevolg hiervan is taalbeinvloeding, warvan aspekte in par. 8.3 behandel is. Maar Engels tas Afrikaans nie uițluitlik struktureel aan nie. Die Engelse disjunkte skryfwyse van "samestellinge" versteur die Afrikaner se persepsie van die begrip 'samestelling'. Deur grootskalse blootstelling aan die Engelse model, word die Afrikaner gekondisioneer. Hy raak gewoon aan die Engelse model. Dit word vir hom die ortografiese norm. Die Engelse model gaan dien dan as wysigingsfaktor oor die taalgrens heen --- in analogieproses.

\subsection{Relatiewe doeimatigheid}

In die Afrikaanse woordelys en Spelreëls, p. 30 lees ons: "'n Hoofletter is een van die middele om nadruk op ' $n$ bepalde woord te lê..." Die los Engelse skryfwyse leen hom tot die benutting van die trefkrag en status van die hoofletter. By die tipe "eienaam plus soortnaam" kan ook die tweede komponent in Engels met ' $n$ hoofletter geskryf word; in Afrikaans nie, byvoorbeeld Eng. Toyota Bakkle, Afr. Toyotabakkle of Toyota-bakkle. By die tipe "soortnaam plus soortnaam" kan albei komponente in Engels 'n hooflettet kry, in Afrikaans slegs die eerste lid, Vergelyk Cash sale, Rontantuitverkoping. Uit 'n reklame-oogpunt is die Engelse model buigsamer, funksioneler en doelmatiger as die Afrikaanse. In Engels word die name van Eirmas, matskappye, rade, geboue, ensovoorts met hoofletters geskryf, byvoorbeeld Natal Technikon, Standard Bank, United Building Society. Dit is 'n ou, gevestigde ortografiese tradisie. Waar dergelike hooflettername of -woorde teenoor die Afrikaanse ekwivalente verskyn, byvoorbeeld op geboue, in beiefhoofde, in reklamestukke, ensovoorts, lyk die Afrikaanse vorm, gemeet an die gevestigde model, ordinêr, vreemd, lomp -.. soos in gereduseerde weergawe van die toonaangewende "standaardvorm". Vergelyk. byvoorbeld Santambank $x$ Santam Bank, Jan Smutglughawe;Jan Smuts-lughave $x$ Jan Souts Airport. Lyk die Engelse vorm, tipografies (en esteties?) beskou. nie meer ewewigtig, die dele meer in harmonie met mekar as die Afrikanse ekwivalente nie? Bet Winskoop Verkopings in 'n advertensie nie groter 
Die navolging van die los skryfwyse van Engels in die onderhawige verband raak nie die wese van Afrikans nie. Dit versteur nie die aard van Afrikans nie. Dit is iets uiterliks wat geraak word --- 'n ortografiese konvensie. Ook besef ons dat dit onmoontlik is om die Engelse skryfwyse in suid-Afrika aan te pas by die Afrikaanse. Alles in aanmerking genome wil dit voorkom dat die afwyking van die Aftikaanse skrytreël 'n natuurlike, spontane vorm van casionalisering op taalgebied in suid-Afrika is --- tot voordeel van Afrikaans: Dit verhoog die bruikbarheid van Afrikaans en dit plaas Afrikaans in ' $n$ beter bedingingsposisie met Engels in dardie gebruikstere war Afrikans ' $n$ sekondêre, selfs 'n tersiêre, tunksie vervul. Was Suid-Afrika ' $n$ Afrikaans eentalige land, vry van Engelse invloed, sou daac stellig nie behoefte aan so ' $n$ aanpassing gewees het nie.

\subsubsection{Erkenning deur die Taalkommissie?}

Die reëlmaat warmee en die skaal warop samestellinge los geskryf word in advertensies en programme op televisle, het daartoe gelei dat die KTA Uit radeloosheid " $n$ versoek aan die Taalkommissie gerig het om die huidige skryfwyse van die tipe "eienaam plus soortnaam" in hersiening te neem. Die Taalkommissie het reeds by wyse van 'n interimbesluit die knellende Reël VII 15 (Afrikaanse woordelys en Spelreëls, p. 13) gewysig met die toevoeging van ' $n$ opsionele reël, sodat die tipe hoof- nediese beapte ook as noof mediese beampte geskryt kan word. Die toevoeging is oral as ' $n$ verlossingsreël verwelkom. Maar dit is 'n geïsoleerde geval. Die Taalkomissie is nietemin bewus van die spanning tussen die Afrikaanse en Engelse skryfwyse van verbindinge. Dat die toepassing van die aanmekarskryfreëls soms probleme oplewer, besef die Taalkommissie terdeë, soos blyk uit ' $n$ opmerking in die Afrikaanse woordelys en spelfeëly, p.39: "Die grootste moeilikheid lê by die vasskrywery." 
http://spilplus.journals.ac.za/

Die probleme wat by die SAUK opduik met betrekking tot die toepassing van norme en die uitreiking van taalgebcuiksvoorskrifte hou in bepalde sin verband met die meertalige situasie in Suid-Afrika. Die Afrikanstalige bevolkingsdeel en sy taal bestaan nie in afsondering van die ander taalgroepe en hulie tale nie. Meectaligheid werk voortdurend interaksie in die hand tussen die onderskeie tale en tussen die verskillende taal-en kultuurgroepe. Die betrekkinge en verhoudinge tussen (taal-)groepe is vanselfsprekend ' $n$ gevoelige aangeleentheid--- nie net in politieke opsig nie.--- warby. taalgebruik 'n belangrike rol speel: Die taalgebruik van groep A openbaaf sy gesindheid teenoor groep B, $C$, en so meer. Taalgebruik help kweek onderlinge groepsverhouding. Deur onverskillige taalgebruik kan betrekkinge tussen groepe vertroebel word; deur gevoelige, bedagsame taalgebruik kan gesonde, ewewigtige verhoudinge gekweek word. Normering in Af * rikaans kan dus nie onderneem word asof die Afrikaanstalige groep in isolasie van die ander groepe verkeer nie. Daar moet rekening gehou word met die voorspelbare reaksie van ander taalgroepe op Afrikaanse taalgebruik en met die inwerking van die ander tale op Afrikaans.

\subsubsection{Inagneming van groepverhoudinge}

Die programme wat die sauk uitsaai, staan tot die beskikking van enige taal- of kultuugroep in Suid-Afrika. ' $n$ Baie belangrike aspek van die taalbeleid van die Afrikanse diens is dat die taalgebruix nooit enige talgroep aanstoot mag gee nie, ongeag of dit 'n nie-Afrikaanstalige of ' $n$ Afrikaanstalige groep is, Daar word dus rekening gehou met die wardes, gebruike, sentimente, tradisies en ander gevoelighede van alle groepe in godsdienstige, morele, etniese, polltieke en ander opsigte. Een onvermydelike gevolg van die beleid is dat sommige taalmateriaal (woorde, terme, gesegdes ...l wat deur leksikograwe, taalkundiges en ander vakkundiges as normal of standard in hulle publikasles bestempel word, onbruikbaar verklaar moet word vif uitsendings. In plas van dergelike items word gebruik gemak van sinonieme uit die standardtaal of die volkstaal (byvoorbeeld stceekvariante), sinonieme terme ult die vaktal, van nuutskeppinge (neologismes) en, as daar nie 'n ander uitweg is nie, selfs van ontleninge, sy dit as tussentydse noodshulp. 
http://spilplus.journals.ac.za/

\section{B.21 Voorbeelde}

Asiër word vereis in plaas van Asiaat omdat laasgenoemde aanstoot gee; die taal- en volkekundeterme Rhoi of Rhoekhoens in plaas van Hottentots (die taal), khoi of khoekhoens in plaas van Hottentot(-te) (groepnaam). In die ongangstaal word soms na godsdienstige feesdae en Eeeste van ander bevolkingsgroepe, byvoorbeeld die Hindu en Moslew, verwys met vakansiedag en vakansie. In Afrikanse programme mag dit nie gebeur nie. Rooms word uit die toon beskou in ' $n$ konstruksie soos ' $n$ Roomse gebruik in plaas van Rooms-katolieke gebruik; ook die amptelike benaming Roons-Ratolieke Rerk word verlang -.. nie Roomse Rerk nie. Ten spyte daarvan dat lidmate van die Gereformeerde kerk in informele situasies soms self van Dopper praat. gebruik die sauk lidmaat van die Gereformeerde Rerk; insgelyks lid và die progressiewe Federale party, nie Prog nie, in teenstelling met die pers warin verwysings soos Prog, Nat, ensovoorts gewoon is. In plaas van tuinjong en aanverwante vorme word van tuinhulp of tuinier gebruik gemaak. In hierdie kader hoort ook broodboon of sikadee, katoenbaai, koraalboon, nakataankonfyt, sorghum(-bier), valvink, zulupot, xhosahut en verskeie ander warvan die gestigmatiseerde sinonieme ongeskik geraak het vir gebruik in radio- en televisieprogramme. Op die ontleende segswyse katte en honde reën is reeds gewys. 'n Aspek wat (meer?) aandag verg, is die voorkoms van afgetakelde sinsbou in dialoog tussen swart en Blanke karakters in $f$ ilms wat deur private matskappye vervaardig word (Steyn 1980:292).

\subsubsection{Woordeboeke ontoereikend}

In AErikaanse woordeboeke (ook tweetaliges) word gewoonlik aangedui watter woorde, woordvorme, ensovoorts ongebruiklik, gewestelik, verouderd en Anglisisties is. Indien items met in stigma in etniese en ander opsigte eweneens gemerk kan word en daar terselfdertyd sorg gedra word dat geskikte sinonieme verstrek word, kan dit die werk van draaiboekskrywers, joernaliste en vertalers aansienlik vergemaklik. Hierdie aspek verg ook meer aandag van die beskrywende taalkunde. Die uitkomste van ondersoeke na taalvariasie kan moontlik bruikbare materiaal vir leksikograwe oplewer. veral met betrekking tot geskikte sinonieme. 
http://spilplus.journals.ac.za/

T.J.R. Botha 264

B.4.3 Pealisme met betrekking tot taalverandering

B.4.3.1 Afhanklikheid van gesaghebbende bronne

Uiterard leun die personeel (en medewerkers) van die Afrikaanse Diens, ook die KTA, swar op die leiding van gesaghebbende bronne soos woordeboeke, met inbegrip van uitspraak-, sinoniem- en vaktaalwoordeboeke, gramnatikas, monografieë oor Anglisisthes, sintaksis, spreekwoorde, ensovoorts, asook op taalgidse wat spesiaal op hoëtrekwensieprobleme in die taalpraktyk roegespits is, byvoorbeeld die juiste voord van Hienstra en spies, en Die korrekte woord yan van der Merwe en Ponelis. Die graad van betroubaarheid van dergelike bronne en die geldigheid van hulle norme is vir die Afrikanse Diens van kardinale belang. $O i t$ is te begrype dat die KTA en leidinggevende personeel nie ligtelik afwyk van erkende bronne nie. ongelukkig word afwyking ten opsigte van bepalde aspekte en gevalle genoodsaak.

\subsubsection{Gesag van Atrikaans versus gessg van Nederiands}

Daar bestaan geen reguerdiging vir die volharding met Nederlandse norme wat in stryd met Afrikaans is nie. In leidende bronne is huiwering te bespeur, selfs traagheid, om erkenning te verleen aan veranderinge wat tussen Nederlands en Afrikaans ingetree het nádat Afrikaans sy hoof onderskeidende kenmerke (byvoorbeeld die verlies van grammatlese geslag, die imperfektum, die sterk werkwoordstelsel, ensovoorts) ontwikkel het. Daar is reeds verwys na die gevorderde stadium van verandering ten opsigte van aksent (par. B.2.7.3 en 8.2.7.4) en na taalverandering onder invloed van Engels (par. 9.3). Hierby kan onder andere woordbetekenis gevoeg word, 'n aspek warby daar soms, ten koste van AErikaans, met Nederlands volgehou word, gelukkig op beperkte skaal. Die volgende voorbeelde kom uit drie erkende woordeboeke, ramilk Odendal: Verklarende handwoordeboek van die Afrikaanse taal, De villiers, et al.: Nasionale woordeboek en Bosman et al.: Tweetalige woordeboek. Volgens die drie bronne beteken eventuejel "moontlik, gebeurlik", nie "uiteindelik" nie; stellig beteken "ongetwyfeld, beslis, werklik seker, bepaald", en nie "warskynlik" nie, hoewel die Tweetalige woordeboek lasgenoemde betekenis toevoeg. Die uitdrukking aan die man bring beteken volgens aldrie "verkoop", nie "vang, arresteer, openbaar" nie. Aan baie op jou kergtok hê word slegs 'n pejoratiewe betekeniswarde geheg, nie ook ' $\rightarrow$ gunstige nie. Ten opsigte van eventueel hou die 
http://spilplus.journals.ac.za/

Afrikaanse Diens ook nog vol met die tradisionele betekeniswarde, maar by die ander drie gevalle word betekenisverandering erken. Die verknogtheid aan Nederlands gee anleiding tot kunsmatige en valse normering in Afrikans. Hierdeur word die ontvoogding van Afrikaans in die wiele gery en die taalgebruiker geintimideer. Sonder on afbreuk te wil doen aan die warde wat Nederlands nog steeds vir Afrikans het, moet erken word dat Nederlands as faktor in die ontwikkeling van Afrikaans al hoe geringer word, terwyl die ander plaaslike tale, by uitstek Engels, in toenemende mate invioed op Afrikans uitoefen.

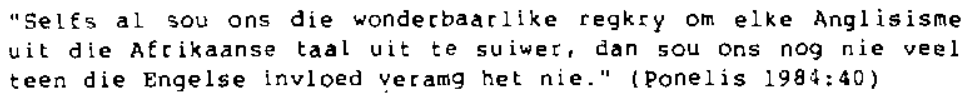

8.4.2.3

Bevryding

Indien die normeerders van Afrikaans die neiging ontgroei am Afrikans aan Nedeclands te meet, en in ' $n$ groter mate versoen raak met die beïnloeding van Afrixaans deur die tale wartussen Afrikaans hom bevind, en met verandering wat Afrikans ondergaan, ongeag die asnleiding daartoe, behoort dit die taalgebruiker te bevry van die las van onsekerhede en teenstrydighede warmee hy gekortwiek word. Afrikaans het sy vierke nodig. Vit die Afrikanse Radio- en Televisiediens kan realistieser normering slegs verligting en voordeel inhou. 
http://spilplus.journals.ac.za/

\section{NOTE}

Oorspronklik was daar twee "komitees van taalgeleerdes": een in Transval en een in die Kaap. Dié onpraktiese reëling het probleme geskep. Die twee komitees is vervang deur ' $n$ enkele komitee waarvan die $S$.A. Akademie, in medewerking met die SAUK, die lede benoem het uit Akademiegeledere. Met ver loop van tyd het hieruit ontwikkel 'n vaste advieskomitee, onder voorsitterskap van die Hoot: Afrikaanse (Radio-) Diens en samgestel deur die SAUK.

2 Die Engelse Diens beskik oor sy eie advieskomitee.

1 Die Englese en Swartaaldienste beskik oor hulle eie taaladviseurs.

- $T k$ = Taalkaatjies.

$5 \quad N=$ Notule van KTA; die syfer na die jaartal dui die maand aan warin die vergadering gehou is.

- "slegs waar in karakter": slegs geoorloof war dit noodsaaklik is in ' $n$ rol wat 'n bepalde karakter vectolk.

, Van prof. J.G.H. Combrink verskyn 'n oorsigtelike hoofstuk oor hierdie k westieuse aspek in Botha et al. Inleiding tot die Afrikanse taalkunde (1984). Vergelyk ook (De Villiers 1970 ).

- Die betrokke skryfreëls in Engels is meer gekompliseerd as die Afrikaanse, maar vir ons doel is dit nie ter sake nie. Let nietemin daarop dat Engelse ekwivalente van Afrikaanse samestellinge dikwels ook vas geskryf word, byvoorbeeld beerhall $x$ beer drinker, winepress, winefarmer $x$ ine district. 


\section{BIBLIOGRAFIE}

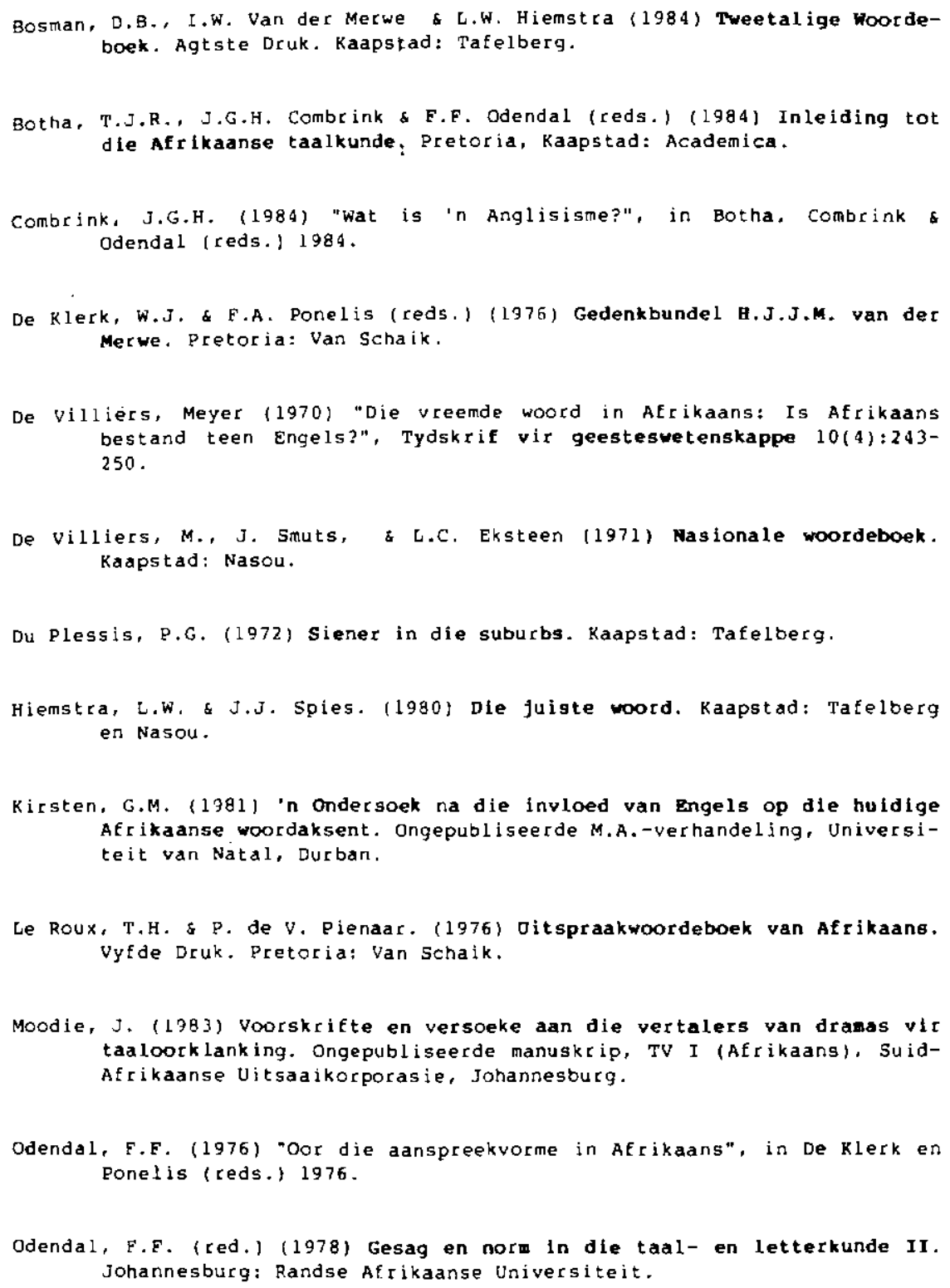


Odendal, F.F. (red.) (1979) Verklarende handwoordeboek van die Afrikaanse taal. Johannesburg: Perskot.

Odendal, F.F. (1984) "Taal en die gemeenskap", in Botha, Combrink 6 Odendal (reds.) 1984 .

Ponelis, F.A. (1984) "Afrikaans binne meertalige verband", in Prinsloo b Van Rensburg (reds.) 1984.

Prinsloo, K.P. \& M.C.J. van Rensburg (reds.) (1984) Afrikaans: Stand, taak, toekoms. Pretoria: KAUM.

Raidt, E.H. (s.j.) Afrikaans en sy Europege verlede. Kaapstad, Bloemfontein, Johannesburg: Nasou.

Steyn, J.C. (1980) Tuiste in eie taal. Kaapstad: Tafelberg.

Suid-Afrikaanse Akademie (s.j.) Afrikaanse woordelys en spelreëlg. Kaapstad: Tafelberg.

Van der Merwe, Carel s Hendrik Engelbreg (1984) Taalbulletin. Johannesburg: SAUR.

Van der Merwe, H.J.J.M. \& F.A. Ponelis (1982) Die torrekte woord. Sesde Druk. Pretoria: Van Schaik.

Van Wyk, E.B. (1978) "Sostolinguistiese norme in taalgebruik", in Odendal, E.F. (red.) 1978. 